\title{
Remembering the Revolution: Dissent, Culture, and Nationalism in the Irish Free State
}

Review Number: 1875

Publish date: Thursday, 7 January, 2016

Author: Frances Flanagan

ISBN: 9780198739159

Date of Publication: 2015

Price: $£ 60.00$

Pages: 272pp.

Publisher: Oxford University Press

Publisher url: http://ukcatalogue.oup.com/product/9780198739159.do

Place of Publication: Oxford

Reviewer: Sean Ledwith

Next year will witness the 100th anniversary of the Easter Rising, the pivotal event that initiated the traumatic creation of the Irish Republic. It can be confidently predicted that both academic and popular discourse leading up to the milestone will revolve around the issue of the extent to which a supposedly sophisticated and democratic modern state should explicitly trace its inception back to a violent and abortive seizure of power in a seemingly remote era. Public opinion both within and without the island of Ireland will undoubtedly be divided between those who regard 1916 as a heroic chapter to be celebrated and acknowledged by the contemporary Irish state, and those who perceive the uprising as an embarrassing aberration that merits minimal commemoration. Renewed interest in the events of that year will inevitably trigger further discussions of the subsequent War of Independence and Civil War of the early 1920s which served as bloody sequels to the Rising. Frances Flanagan's monograph Remembering the Revolution serves as a thought-provoking and impressively researched primer for those debates to come, and also as timely reminder that the controversies surrounding the nature of that Irish insurrectionary wave were explored by the first post-revolutionary generation with a vigour that matches any modern polemic.

She is particularly concerned with four writers who lived - and in some cases, fought - to see Ireland's incomplete separation from Britain, only to become disillusioned with the state that arose out of the struggle for independence. Flanagan writes: 'This book examines the lives of a group of men who were similarly dismayed by the events that came to pass and attempted to chronicle the revolution in a critical fashion that was strikingly at odds with myths of revolution revered and rehearsed by politicians and popular writers on both sides of the Treaty divide' (p. 2). This orientation on an iconoclastic approach to 1916 and after is underlined at the outset as the author implicitly states her allegiance to the school of Irish revisionism, championed most notably by Roy Foster (p. vii). This historiographical paradigm arose in the 1970s partly as a response to the resurgence of political violence in Northern Ireland. Foster's perspective was founded on the notion that the turbulence of previous decades had been largely caused by atavistic forms of irrationality and fanaticism in the Irish psyche that were being gradually denuded by the generations that have followed. He developed a predominantly negative outlook on the Easter Rising that suited the interests of politicians on both sides of the border - and both sides of the Irish Sea - who wanted to downplay the significance of 1916 and focus their supposedly more efficacious activity on constitutional methods of change. The Good 
Friday Agreement of 1998 appeared to represent the culmination of both hopes for peaceful reform in the present and Foster's desire for revised paradigms of the past. Flanagan largely resists the temptation to draw comparisons between the visions of the revolutionaries of the early 20th century and the more prosaic reality of the Southern Irish state today but she leaves little doubt that she shares Foster's view that their idealism was misguided at best and calamitous at worst. She imagines the fighters of the struggle for independence growing old with 'the haunting thought that with each march, book and speech of remembrance another future they had once worked towards would recede further from view' (p. 203).

The four writers she selects from the revolutionary era are labelled as 'proto-revisionists' for their anticipation of the concerns of historians who would come after them (p. 6). Flanagan accepts the comparison between generations is only partly useful as the first had a personal stake in the events that the latter could not hope to reproduce. The writers of 1916 and its aftermath 'did not speak from a position of detachment, a "view from nowhere", but rather from places of entanglement, as cultural revolutionaries who had heavily invested their lives in a movement that they expected to proceed in a particular direction' ( $\mathrm{p}$. 198). The first of her subjects, Eimar O'Duffy, could take minor responsibility for the military failure of 1916 as he informed the head of the Irish Volunteers, Owen Mac Neill, that an uprising was imminent hours before its commencement. McNeil's subsequent refusal to participate denied the rebels in the GPO thousands of men who might have made the difference between victory and defeat (p. 58). P. S. O'Hegarty personally enrolled young Michael Collins, the future nemesis of the British secret service, into the Irish Republican Brotherhood, while they both worked for the post office in London (p. 97). Her third author, George Russell, was active in raising support for the strikers of the 1913 Dublin Lockout which served as a curtain-raiser for the years of rebellion that followed (p. 126). Flanagan's final subject, Desmond Ryan, fought alongside Pearse, Connolly, McDonough and the other iconic leaders of the battle for the GPO (p. 167) and witnessed first-hand the British massacre of football spectators at Croke Park four years later (p. 174).

The four authors she identifies as symptomatic of the post-independence intelligentsia are not household names outside Ireland but Flanagan argues their disillusionment with the nationalist cause was also shared by more familiar figures of the same generation. W. B. Yeats was 'profoundly alienated by the narrow, puritanical and Catholic bourgeois nationalism that abounded in the new state' (p. 30). The plays of Sean O'Casey provoked riots in Dublin with their jaundiced portrayal of the motivation and behaviour of the rebels of 1916 (p. 23). Likewise performances of John Synge's 'Playboy of the Western World' had been disrupted by outraged audiences in the period prior to the Rising (p. 44). Sean O'Faolain 'wrote scathingly of the repetitive, shrill sentimental and anti-intellectual qualities of Republican discourse' (p. 26). Flanagan is undoubtedly correct that these writers of global stature expressed vividly the sense of physical and philosophical exhaustion experienced by many in the Southern Irish state in the inter-war period. One of the book's few shortcomings, however, is the scarcity of historical contextualisation of why the Irish revolution had run out of momentum by the time these authors were creating their most powerful work. Flanagan echoes the revisionist notion that Republican ideology contained intrinsic defects that inevitably mutated into the fratricide of the civil war and the ossification of the government presided over by DeValera and others. The religiosity of many of the revolutionaries is perceived as a crucial brake on any progressive tendencies that might have existed among them: 'revolutionary activity was presented as an answer to a transcendental call from a higher power, rather than being the product of rational decision-making and individual agency in the earthly realm' (p. 17). Flanagan thus prompts a healthy scepticism regarding the more reactionary elements of the Republican movement of the time and a necessary reminder of the civilian cost of the struggle. However, the absence of significant analysis of either the insidious role played by the British state in cultivating the idea of partition or the repressive excesses of its hired killers, the Black and Tans, engenders a limited understanding that will not assist readers unfamiliar with the period. The prevalence of Catholic ideology among the 1916 generation needs to be historicised as more than a backward relic of a threatened way of life. Such a belief-system served as a convenient but dynamic outlet for the expression of revolutionary ideas among a population struggling to find its voice after decades of oppression at the hands of the Anglo-Irish ascendency. Flanagan usefully notes how 'socialist radical 
elements in the revolutionary movement were largely erased', but her one-dimensional treatment of the dominant religious strain among the forces of the anti-British resistance could have been more nuanced ( $\mathrm{p}$. 22). As she focuses on four male writers, there is little that would alert the reader to the not-insignificant feminist agenda that featured amid the events of the Rising, such as Connolly's insistence that the Proclamation of the Republic include the rights of men and women, or the fact that there were over 30 women fighting alongside him in the GPO.

The insular tendency of Flanagan's perspective on the period is particularly ironic as one of the more valuable insights of her account is a highlighting of the desire of the writers she analyses to re-connect Irish culture to its roots in a common European experience of the classical world. She describes how Eimar O'Duffy's play, 'The Walls of Athens' contrived to make a comparison between the exhausted Athens of the post-Periclean era and the spiritual emptiness of Britain on the eve of the First World War (p. 54). According to O'Duffy, 'Irish cultural achievements had to be understood in a long comparative and international perspective. Some ancient Gaelic literature was comparable to the canonical authors of Ancient Greece and Rome' (p. 64). O'Hegarty shared this sense of the importance of continental influences on the development of Ireland (p. 114). Russell 'thought the suitable analogues for Irish nationalism were the classical civilisations of Egypt, Assyria, Greece and Rome' (p. 144).The abortive nature of the Irish revolution evidently led these authors to seek spiritual solace in the supposed harmony of social formations in antiquity. Such reveries might have been suitable for intellectuals seeking to escape the complexities of a political struggle in the 20th century but they represented a step backwards for the cause of progressive politics in Ireland.

The desire of these figures to evade the challenges of the revolutionary movement in its post-civil war phase is even more apparent in their frequent embrace of mysticism and the occult. O'Duffy ended up in the 1930s preaching a form of Bergsonian vitalism and railing against the mechanism he perceived in the new Free State (p. 79). Russell became an affiliate of 'Helena Blavatsky's notion that the world was on a cyclical trajectory that destined it to pass from a phase of materialism to a period of spiritual growth around the turn of the century' (p. 124). Desmond Ryan had earlier been drawn to anthroposophy and the alternative educational philosophy of Rudolf Steiner as a young man (p. 176). The ambivalent outcome of the war for liberation also led them to abandon the democratic impulses that had inspired the best of the generation of 1916. O'Duffy flirted with eugenics as a possible solution to the supposed inferiority of the mass of his compatriots who he labelled as 'ignorant, stupid, dirty, diseased and ugly' (quoted on p. 72). O'Hegarty was unapologetic in his elitism, 'emphasising the sense that increases in national awareness were the product of the painstaking unpaid work of a tiny minority' (p. 101). George Russell came to believe that a narrow intellectual elite were responsible for any worthy element in Irish society that had survived the upheavals of the revolutionary era: 'A constant theme in his interpretation ... was that the constructive aspects of the revolution were started by himself and his circle and particularly Standish O Grady' (p. 161). The source of the appeal to these writers of the classical world in which essentially an unproductive but cultured elite presided over a toiling mass of humanity becomes apparent in light of their disengagement from and disillusionment with a popular movement.

A more progressive aspect of the thought of the four subjects in the twilight of their careers was a willingness, against the grain of most of their contemporaries, to embrace the radical nature of literary modernism as it impacted in Europe in roughly the same period as Ireland's bid for freedom. Flanagan perceptively notes how these Irish writers were all appreciative of the work of James Joyce, their compatriot and trailblazer of the movement. O'Hegarty greeted 'Ulysses' as the defining masterpiece of the century ( $\mathrm{p}$. 106). Russell regarded the writer as one of a golden generation of Irish geniuses - although strangely, Flanagan does not mention that Russell features as a character in the novel (p. 159). Desmond Ryan was 'influenced deeply by Joyce' (p. 195). For O'Duffy, the novel 'confirmed his conviction that true patriotism in Ireland was not the province of the gunman or the political theorist but rather the common man' (p. 69). Joyce's appeal to this quartet of writers is understandable as he shared their baleful view of the British role in Ireland but also found himself unenthusiastic about the state which arose to replace it. 
The co-existence of reactionary and progressive elements in the thinking of the four authors is personified in their respective attitudes to Michael Collins, the most intriguingly ambivalent figure thrown up by the struggle for independence. Collins had been the organisational genius behind the guerrilla war to drive out the British in the War of Independence, but then became the most crucial apologist for the partition of 1921 that would condemn Ireland to decades of political sterility. In 1918, O'Hegarty tried to persuade Collins that the continuation of armed struggle would be in vain (p. 92). Four years later, O'Duffy edited a newspaper set up by Collins to justify the Anglo-Irish Treaty (p. 68). One of Desmond Ryan's works, 'The Invisible Army', drew praise from Collins' sister for its sympathetic portrayal of her brother (p. 185).

Russell summed up the contradictions embedded in the figure of the Free State's lost leader with a comment in 1926 that 'Collins was no Collinsite', implying that the complexity of the man had become occluded by caricature and partisanship (p. 149).

Cumulatively, Flanagan develops a fascinating collective portrait of a group of authors whose contradictions and anomalies mirror those of the insurrectionary wave that shaped their consciousness. The Easter Rising came less than one year before the outbreak of Russian Revolution of 1917, and might easily have followed a radically different historical trajectory had it been integrated with a broader European movement for social and political transformation. The determination of the British state to partition its oldest colony created two societies on either side of the border that, in different ways, froze the remarkable cultural revolution that was underway in Ireland in the years leading up to 1916. O'Duffy, O'Hegarty, Russell and Ryan represent a lost generation of Irish intellectuals that rode the wave of revolution, only to end up beached when it ran out of momentum. As Flanagan observes, the relevance of their situation goes beyond Ireland itself: 'their biographies have a powerful capacity to illuminate a set of mentalities which have existed in numerous postrevolutionary contexts in the modern era' (p. 3). Her book is a thoughtful and scholarly contribution to an understanding of a generation that tried to change the world and had to live with the consequences of failure.

Source URL:https://reviews.history.ac.uk/review/1875

\section{Links}

[1] https://reviews.history.ac.uk/item/147169 